\title{
RT-PCR em pools de soros sangüíneos para o diagnóstico da infecção aguda e de animais persistentemente infectados pelo vírus da diarréia viral bovina
} \author{
bovine viral diarrhea virus] \\ D. Pilz ${ }^{1}$, A.F. Alfieri ${ }^{2,3}$, M. Lunardi ${ }^{1}$, A.A. Alfieri ${ }^{2,3 *}$ \\ ${ }^{1}$ Aluno de pós-graduação - UEL - Londrina, PR \\ ${ }^{2}$ Laboratório de Virologia Animal - UEL \\ Caixa Postal 6001 \\ 86051-990 - Londrina, PR \\ ${ }^{3}$ Bolsista do $\mathrm{CNPq}$
}

[RT-PCR in pools of bovine blood serum to detect acute infection and persistently infected animals with

\begin{abstract}
RESUMO
Utilizou-se a técnica da RT-PCR para a detecção da região 5 ' UTR do genoma do vírus da diarréia viral bovina (BVDV) em pools de soros sangüíneos provenientes de um rebanho, constituído por 226 animais, que apresentava distúrbios da reprodução. A partir das amostras individuais de soro e de acordo com a categoria dos animais e o número de animais por categoria foram formados 10 pools (A a J) de soros. A primeira avaliação revelou a amplificação de um produto com 290pb nas reações referentes aos grupos D (35 vacas) e H ( 25 bezerros lactentes) que, após o desmembramento em amostras individuais, resultou na identificação de 11 vacas lactantes e 12 bezerros em amamentação positivos. Para a identificação de animais persistentemente infectados (PI) entre os 23 positivos na primeira avaliação, realizou-se a segunda colheita de soros sangüíneos, três meses após. A RT-PCR das amostras individuais de soro revelou resultado positivo em cinco bezerros. Em dois, foi possível isolar o BVDV em cultivo de células MDBK. A especificidade das reações da RT-PCR foi confirmada pelo seqüenciamento dos produtos amplificados a partir do soro de uma vaca com infecção aguda, de um bezerro PI e das duas amostras do BVDV isoladas em cultivo celular. A utilização da RT-PCR em pools de soros sangüíneos demonstrou ser uma estratégia rápida de diagnóstico etiológico e de baixo custo tanto para a detecção de infecção aguda quanto de animais PI.
\end{abstract}

Palavras-chave: bovino, diarréia viral bovina, BVDV, RT-PCR

\begin{abstract}
The 5' untranslated region of the bovine viral diarrhea virus (BVDV) genome was detected by RT-PCR assay in pools of blood sera samples collected from a cattle herd ( $n=226$ animals) with reproductive failures. Based on the classes of animal and the number of animals per class, the individual blood serum samples were distributed in 10 sera pools (A to J). During the first evaluation a $290 \mathrm{bp}$ amplicon was amplified in reactions from groups $D$ (35 cows) and $H$ (25 sucking calves). The individual analysis of serum from groups $D$ and $H$ resulted in positive reactions in serum samples from 11 cows and 12 calves. For the identification of persistently infected (PI) animals, three months after the first examination, blood serum samples from 23 positive animals were reevaluated by RT-PCR, resulting in five positive calves. In two of these calves the $B V D V$ was isolated in MDBK cell culture. The specificity of RT-PCR amplicons from one cow with acute infection, one PI calf, and two wild type BVDV strains isolated in cell culture were confirmed by nucleotide sequencing. The use of RT-PCR in pools of blood sera proved to be a quick and low cost strategy for the etiological diagnosis of the acute infection as well as to detect PI animals thereby favoring the implementation of control and prophylaxis measures.
\end{abstract}

Keywords: cattle, bovine viral diarrhea, BVDV, RT-PCR

Recebido em 15 de setembro de 2005

Aceito em 18 de dezembro de 2006

*Autor para correspondência (corresponding author)

E-mail: alfieri@uel.br

Apoio: CNPq/CAPES/FINEP, Fundação Araucária (FAP/PR) 


\section{INTRODUÇÃO}

A diarréia viral bovina (bovine viral diarrhea -BVD) é causada pela infecção do vírus da diarréia viral bovina (bovine viral diarrhea virus -BVDV) que é um membro da família Flaviviridae, gênero Pestivirus. De acordo com o ciclo lítico em cultivo celular, as estirpes do BVDV podem ser classificadas em biotipos citopáticos (CP) e não-citopáticos (NCP). As estirpes NCP freqüentemente estão associadas às diversas manifestações clínicas da infecção enquanto as estirpes $\mathrm{CP}$ são isoladas, principalmente, de casos clínicos de doença das mucosas (Van Regenmortel et al., 2000). A análise molecular da região terminal nãotraduzida 5' (Untranslated Terminal Region 5'UTR) do genoma viral possibilita a classificação das estirpes do BVDV em genotipos 1 e 2 . Técnicas de neutralização cruzada e, principalmente, reatividade a painéis de anticorpos monoclonais têm demonstrado ainda grande diversidade antigênica entre as estirpes do BVDV isoladas tanto de casos clínicos quanto de animais assintomáticos (Hamers et al., 2001). A diversidade biológica, antigênica e molecular do BVDV pode ser responsável por falhas no diagnóstico e na imunoprofilaxia da doença.

A BVD está amplamente distribuída nos rebanhos bovinos de corte e leite de todo o mundo e, também, no Brasil, com taxas de prevalência que podem variar de 60 a $85 \%$ de animais soropositivos (Houe, 1999; Flores et al., 2005). A infecção pelo BVDV pode ser assintomática ou determinar uma gama de sinais clínicos. Devido à sua capacidade imunodepressora podem ser observados problemas entéricos e/ou respiratórios (Pedrizet et al., 1987). Baixa taxa de concepção, abortamento, mumificação fetal, nascimento de animais com defeitos congênitos, mortalidade neonatal e o nascimento de bezerro com peso corporal inferior à média da raça são os sinais mais freqüentes da forma reprodutiva da infecção (Dubovi, 1994).

A infecção fetal entre 40 a 120 dias de gestação por uma estirpe NCP do BVDV, com freqüência, é seguida de persistência viral e indução de imunotolerância (Baker, 1995). Esses fetos originam bezerros persistentemente infectados
(PI) que constituem o elo da cadeia epidemiológica da doença. Animais PI, que podem representar até $2 \%$ nos rebanhos infectados, eliminam constantemente o BVDV por todas as secreções e excreções, favorecendo a disseminação da infecção nos rebanhos (Houe et al., 1995).

O sucesso de programas de controle e erradicação da BVD depende da identificação e eliminação dos animais PI (Bolin, 1990). A técnica laboratorial tradicionalmente empregada com esse objetivo é o isolamento viral em cultivo celular, seguido de imunofluorescência ou de imunoperoxidase para a identificação das estirpes NCP (Houe et al., 1995). Com isso, a técnica torna-se laboriosa, demorada e exige a avaliação individual de todos os animais do rebanho. O método de ELISA apresenta como principal vantagem a redução no período de tempo necessário para a identificação de animais PI. Porém, o ELISA também deve ser realizado em amostras biológicas (soro sangüíneo, plasma ou sangue total) individuais, o que aumenta o custo final do diagnóstico, podendo inclusive inviabilizar o seu uso em situações de rebanhos onde muitos animais devem ser avaliados (Rossmanith et al., 2001).

Os métodos moleculares, desde que devidamente padronizados e avaliados, apresentam altas taxas de sensibilidade e especificidade (McPherson et al., 1994). Devido a essas características, a reação em cadeia da polimerase, precedida de uma etapa de transcrição reversa (RT-PCR), tem sido muito utilizada para o diagnóstico das várias formas de manifestação clínica da infecção pelo BVDV, além da detecção de animais PI a partir de amostras biológicas individuais e em pools de soros sangüíneos (Rossmanith et al., 2001; Weinstock et al., 2001; Pilz et al., 2005).

O objetivo deste estudo foi utilizar a técnica da RT-PCR em pools de soros sangüíneos para a detecção do BVDV em um rebanho de bovinos de corte com histórico de problemas reprodutivos.

\section{MATERIAL E MÉTODOS}

O rebanho, proveniente da região dos Campos Gerais do estado do Paraná, era constituído de 226 animais, sendo 136 vacas, 34 novilhas, 49 
bezerros e sete touros da raça Santa Gertrudes. As fêmeas em idade de reprodução apresentaram histórico de problemas reprodutivos caracterizados por abortamentos, natimortalidade, ocorrência de defeitos congênitos e o nascimento de animais com peso corporal abaixo da média da raça. $O$ acasalamento era feito por monta natural e os animais, na fase de reprodução, eram regularmente vacinados com vacinas comerciais múltiplas contendo o $\mathrm{BVDV}$, o herpesvírus bovino 1 (BoHV-1) e cinco sorovares de Leptospira spp.

Para a detecção do BVDV utilizou-se soro sangüíneo obtido a partir de amostras de sangue que, para evitar contaminação cruzada, foram colhidas e processadas com o auxílio de material estéril, descartável e de único uso. As colheitas de sangue foram realizadas em duas ocasiões, com intervalos de três meses entre elas. Após a retração do coágulo o soro sangüíneo foi recolhido e armazenado a $-20^{\circ} \mathrm{C}$. Inicialmente todos os animais do rebanho foram avaliados. A partir dos soros individuais foram formados 10 pools de soros sangüíneos, distribuídos de acordo com a categoria animal e o número de animais por categoria. Os grupos A $(n=30), \mathrm{B}(n=30), \mathrm{C}$ $(n=30), \mathrm{D}(n=35)$ e $\mathrm{E}(n=11)$ foram constituídos por amostras de soros provenientes de vacas $(n=136)$. As amostras de soros colhidas de novilhas foram distribuídas nos grupos $\mathrm{F}(n=17)$ e $\mathrm{G}(n=17)$ e as de bezerros nos grupos $\mathrm{H}(n=25)$ e I $(n=24)$. No grupo $\mathrm{J}(n=7)$ foram incluídas as amostras de soros provenientes dos touros. Nos grupos que, após a primeira avaliação, resultaram positivos para o BVDV as amostras de soros foram analisadas individualmente. Para a segunda colheita de sangue foram selecionados apenas os animais que resultaram positivos na primeira colheita. Todas as amostras foram mantidas a $-20^{\circ} \mathrm{C}$ até a sua utilização na RTPCR.

A estirpe citopática NADL do BVDV, utilizada como controle positivo na RT-PCR, foi produzida em células MDBK conforme procedimento padrão.

A extração do RNA do BVDV foi realizada a partir de uma alíquota de $50 \mu 1$ de cada pool de soros sangüíneos de acordo com a técnica da sílica/isotiocianato de guanidina descrita por Boom et al. (1990). Em todas as extrações de
RNA foram incluídas alíquotas de água ultrapura $^{1}$ autoclavada (controle negativo).

Para a realização da RT-PCR foram utilizados os oligonucleotídeos iniciadores (primers) 103 sense (5' tag cca tgc cet tag tag gac 3'-nt. 103124) e 372 anti-sense (5' actc cat gtg cca tgt aca gc 3'-nt. 372-392), desenhados a partir da seqüência da região não-traduzida 5'UTR da estirpe NADL do BVDV (Weinstock et al., 2001). A técnica foi realizada de acordo com Pilz et al. (2005), com pequenas modificações. A transcrição reversa foi realizada em uma solução contendo $9 \mu \mathrm{l}$ do RNA extraído e $11 \mu \mathrm{l}$ de RTMIX constituído por $1 \mathrm{pmol}$ do primer 372 , $0,25 \mathrm{mM}$ de cada dNTP ${ }^{2}$, PCR buffer (20mM Tris $\mathrm{HCl} \mathrm{pH} 8,4$ e $50 \mathrm{mM} \mathrm{KCl}), 1,5 \mathrm{mM} \mathrm{MgCl}_{2}, 60$ unidades da enzima transcriptase reversa $\mathrm{M}$ $M_{L V}{ }^{1}$ e água ultra-pura autoclavada para o volume final de $20 \mu \mathrm{l}$. As amostras de RNA foram pré-desnaturadas a $97^{\circ} \mathrm{C} / 4 \mathrm{~min}$ e mantidas em banho de gelo até a adição dos reagentes. A síntese do cDNA foi realizada em termociclador $\left(\mathrm{PTC}-200^{3}\right.$ ) a $42^{\circ} \mathrm{C} / 30 \mathrm{~min}$ com posterior inativação da enzima a $95^{\circ} \mathrm{C} / 5 \mathrm{~min}$.

A PCR foi realizada em uma solução contendo $5 \mu \mathrm{l}$ do cDNA e $45 \mu 1$ de PCR-MIX constituído por $0,4 \mathrm{pmol}$ de cada primer $(103 / 372), 0,1 \mathrm{mM}$ de cada dNTP, 2,5 unidades de Platinum Taq DNA polimerase recombinante ${ }^{4}$, PCR buffer $(20 \mathrm{mM}$ Tris $\mathrm{HCl} \mathrm{pH} 8,4$ e $50 \mathrm{mM}$ de $\mathrm{KCl}), 1,5 \mathrm{mM} \mathrm{MgCl}_{2}$ e água ultra-pura autoclavada para o volume final de $50 \mu \mathrm{l}$. As amostras de cDNA foram pré-desnaturadas a $94^{\circ} \mathrm{C} / 4$ min e mantidas em banho de gelo até a adição dos reagentes. $\mathrm{O}$ processo de amplificação foi realizado em termociclador com as seguintes condições de tempo e temperatura: i) uma etapa de $4 \mathrm{~min} / 94^{\circ} \mathrm{C}$; ii) 35 ciclos de $1 \mathrm{~min} / 94^{\circ} \mathrm{C}, 30 \mathrm{~s} / 59^{\circ} \mathrm{C} \mathrm{e}$ $1 \mathrm{~min} / 72^{\circ} \mathrm{C}$; iii) uma etapa de extensão final de $7 \mathrm{~min} / 72^{\circ} \mathrm{C}$.

Os produtos da RT-PCR foram submetidos à eletroforese em gel de agarose a $2 \%$, contendo brometo de etídeo $(0,5 \mu \mathrm{g} / \mathrm{ml})$, em tampão TBE pH 8,4 (89mM Tris; $89 \mathrm{mM}$ ácido bórico; $2 \mathrm{mM}$

${ }^{1}$ Milli-Q ${ }^{\circledR}$ plus, Millipore Co., EUA

${ }^{2}$ Invitrogen ${ }^{\mathrm{TM}}$, Life Technologies, EUA

${ }^{3}$ MJ Research Co., EUA

${ }^{4}$ Invitrogen ${ }^{\mathrm{TM}}$, Life Technologies, BR

${ }^{5}$ Gibco BRL, EUA

${ }^{6}$ Sigma Co., EUA

${ }^{7}$ Qiagen, EUA

${ }^{8} \mathrm{GE}$ Healthcare, GB 
EDTA), sob voltagem constante $(90 \mathrm{v})$ por 30 min e visualizados sob luz ultra-violeta (UV).

Para o isolamento do BVDV a partir dos animais que, por duas vezes consecutivas, resultaram positivos na RT-PCR alíquotas de $500 \mu$ do soro sangüíneo, provenientes da segunda colheita, foram inoculadas em tubos contendo monocamada pré-formada de células MDBK, mantidas em meio de cultura celular D-MEM ${ }^{5}$ sem $\mathrm{SFB}^{5}$ e suplementado com antibióticos ${ }^{6}$ (penicilina $50 \mathrm{UI} / \mathrm{ml}$ e estreptomicina $50 \mathrm{mg} / \mathrm{ml}$ ). Os tubos foram incubados a $37^{\circ} \mathrm{C}$ em sistema de roller e monitorados diariamente quanto à presença de efeito citopático (ECP) característico de estirpes CP do BVDV. Passagens adicionais eram realizadas a cada cinco dias. Após três passagens sucessivas, sem a visualização de ECP, as amostras eram avaliadas pela RT-PCR para a possível detecção de estirpes $\mathrm{NCP}$ do BVDV. Tubos controle contendo células MDBK não inoculadas foram mantidos em todas as passagens.

Os produtos com 290pb da RT-PCR, provenientes de uma vaca com infecção aguda, de um bezerro PI e das duas amostras do BVDV isoladas em cultivo celular a partir do soro de bezerros PI, foram purificados (QIAquick PCR Purification $\mathrm{Kit}^{7}$ ) e seqüenciados (MegaBACE 1000/Automated 96 Capillary DNA Sequencer ${ }^{8}$ ). A qualidade de cada seqüência obtida foi analisada com o software Phred/Phrap/Consed Analysis Program (http://www.phrap.org/) e a homologia das seqüências foi comparada com as seqüências depositadas no GenBank por meio do software BLAST (http://www.ncbi.nlm. nih.gov/BLAST).

\section{RESULTADOS E DISCUSSÃO}

A primeira avaliação dos 10 grupos de pools de soros sangüíneos analisados pela RT-PCR revelou dois grupos positivos. Produtos amplificados com 290pb foram observados nas reações referentes ao grupo $\mathrm{D}$, constituído por soros de 35 vacas, e ao grupo $\mathrm{H}$, formado por 25 soros de bezerros lactentes (Fig. 1).

Com a realização de apenas 10 reações de RTPCR foi possível identificar infecção ativa pelo BVDV no rebanho avaliado, bem como determinar a categoria e os grupos de animais com infecção aguda. Como a análise foi realizada a partir de amostras de soro sangüíneo, os resultados positivos sugerem que o BVDV estava em fase de viremia nos animais que resultaram positivos. Durante o período de colheita das amostras biológicas para o diagnóstico ainda estavam ocorrendo natimortalidade e o nascimento de animais com defeitos congênitos e/ou com baixo peso corporal. Esses resultados poderiam explicar a ocorrência dos sinais clínicos observados no rebanho. A utilização de pools de soros sangüíneos possibilitou redução considerável tanto no custo do diagnóstico quanto no tempo necessário para a conclusão dos resultados, uma vez que os 226 animais do rebanho foram avaliados por meio da realização de 10 reações de RT-PCR que foram processadas em apenas dois dias.

Apesar da alta sensibilidade dos sistemas de RTPCR, resultados falso-negativos não podem ser descartados, particularmente considerando que as amostras de soros sangüíneos não foram analisadas individualmente. $\mathrm{Na}$ formação dos pools procurou-se distribuir as amostras entre as diferentes categoriais de animais que constituíam o rebanho, incluindo o máximo de 35 amostras de soro por pool. Entretanto, Pilz et al. (2005), nos trabalhos de otimização da RT-PCR, avaliaram a sensibilidade do sistema e obtiveram reações positivas em pools de soros sangüíneos constituídos por até 160 soros em que um deles foi artificialmente contaminado com a estirpe NADL do BVDV.

O desmembramento dos pools referentes aos grupos $\mathrm{D}$ e $\mathrm{H}$ em amostras individuais resultou na identificação de 11 vacas e 12 bezerros lactentes positivos. Esse resultado também caracteriza a infecção ativa pelo BVDV no rebanho uma vez que, no momento da colheita, 10,2\% (23/226) dos animais apresentaram reação positiva na RT-PCR. A concentração desses 23 animais positivos em apenas dois grupos provavelmente foi devido ao esquema adotado na categorização das amostras individuais em pools. Para a formação de cada pool optou-se inicialmente pela distribuição por categorias e cada categoria por faixa etária. Os grupos H e I de bezerros foram constituídos, respectivamente, por animais com idade inferior e superior a três meses. $\mathrm{O}$ pool $\mathrm{D}$, no qual foram encontradas vacas positivas, foi constituído por animais com duas ou mais crias que haviam apresentado, recentemente, algum distúrbio da reprodução. 


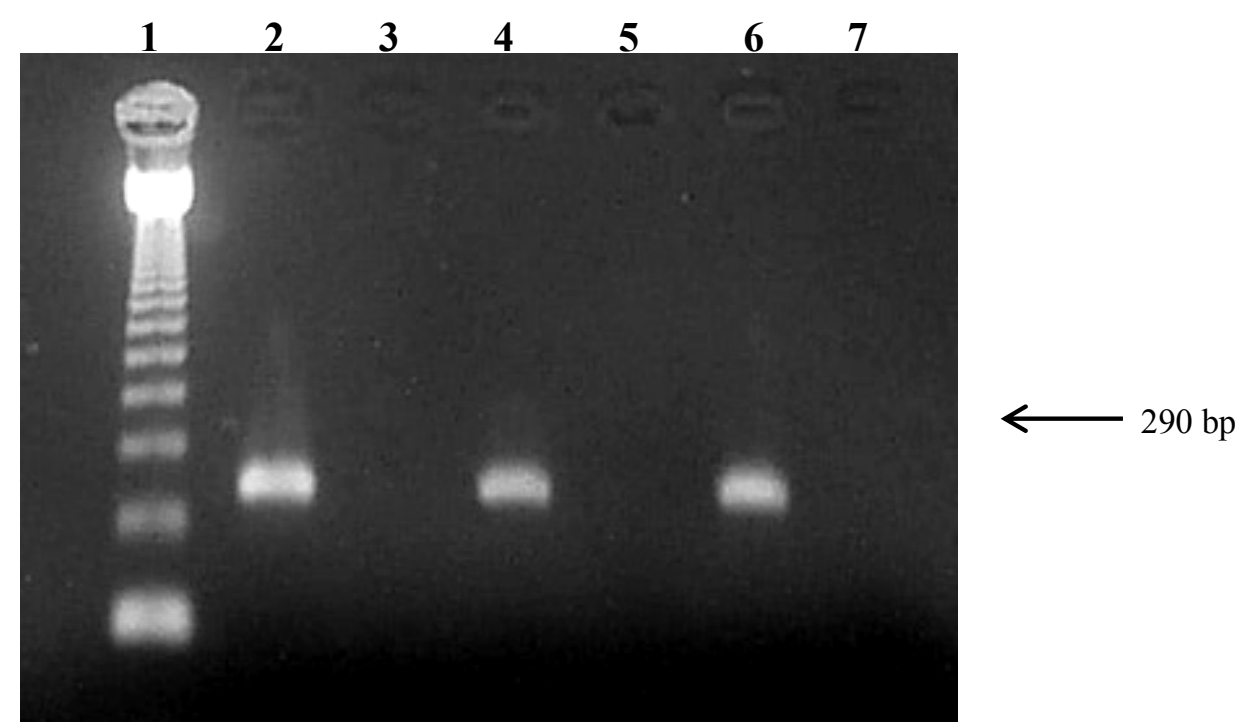

Figura 1. Análise por eletroforese em gel de agarose a $2 \%$ com brometo de etídeo, dos produtos amplificados (290 pb) pela RT-PCR para a região 5'-UTR do vírus da diarréia viral bovina (BVDV) em pools de soros sangüíneos de vacas e bezerros. Canaleta 1: marcador de tamanho molecular 123pb ladder $^{2}$; canaleta 2: estirpe NADL do BVDV; canaleta 3: pool A - soros sangüíneos de vacas negativas $(n=30)$; canaleta 4: pool D - soros sangüíneos de vacas positivas $(n=35)$; canaleta 5: pool I - soros sangüíneos de bezerros negativos $(n=24)$; canaleta 6: pool $\mathrm{H}$ - soros sangüíneos de bezerros positivos $(n=25)$; canaleta 7 : água ultra-pura autoclavada.

A análise das amostras de soros sangüíneos provenientes da segunda colheita, realizada três meses após a primeira, demonstrou resultado positivo em cinco bezerros. Essa segunda colheita foi realizada apenas nos 23 animais que resultaram positivos na primeira avaliação e foi efetuada com o objetivo de identificar a presença de animais PI no rebanho. O resultado positivo encontrado em cinco bezerros, três meses após a primeira avaliação, possibilitou a caracterização desses animais como PI (Brock, 1995). Os bezerros identificados como PI, mesmo recebendo o mesmo manejo nutricional, apresentavam como principal característica o desenvolvimento corporal muito inferior aos animais nascidos no mesmo período e que resultaram negativos na RT-PCR. O fraco desempenho, particularmente com relação ao ganho de peso, é uma das situações mais freqüentes encontradas em animais PI (Baker, 1995).

$\mathrm{Na}$ terceira passagem em células MDBK foi possível o isolamento do BVDV NCP a partir do soro de dois bezerros PI. Devido à ausência de ECP a confirmação do isolamento foi realizada por meio da amplificação de um fragmento de 290pb pela RT-PCR.

As análises das seqüências de nucleotídeos, realizadas com o software BLAST, comprovaram que os produtos de 290pb, amplificados a partir de material biológico de uma vaca com infecção adulta, de um bezerro PI e também das duas estirpes do BVDV isoladas em cultivo celular eram específicos para o BVDV.

A utilização somente da técnica de isolamento viral em cultivo celular, associada a imunofluorescência ou a imunoperoxidase diretas para a detecção das estirpes NCP do BVDV, para o diagnóstico da infecção no rebanho avaliado nesse estudo resultaria em um processo laborioso, de custo elevado e demorado, uma vez que todas as 226 amostras de soro sangüíneo teriam que ser analisadas individualmente. $\mathrm{O}$ isolamento viral apresenta ainda como desvantagem a necessidade da conservação do material biológico em condições que preserve a viabilidade do vírus uma vez que a técnica exige a presença de partículas virais infectantes. Com isto, a RT-PCR tem sido 
utilizada mundialmente como método diagnóstico alternativo. A análise, quando realizada pela detecção direta do genoma viral em amostras biológicas, pode descartar freqüentes resultados falso-negativos em cultivo celular gerados por condições impróprias de colheita, transporte e armazenamento das amostras (Takiuchi et al., 2005).

Todos os animais incluídos na categoria de reprodução do rebanho avaliado eram regularmente vacinados com vacinas comerciais contendo o BVDV inativado, além do BoHV-1 e cinco sorovares de Leptospira spp. Tanto a forma clínica quanto os resultados do presente trabalho sugerem a participação do BVDV na etiologia dos problemas reprodutivos observados no rebanho, bem como caracteriza uma situação real de falha vacinal. Estudos recentes demonstraram que estirpes do BVDV isoladas no Brasil apresentam diversidade genética e antigênica com as estirpes presentes na maioria das vacinas comerciais (Flores et al., 2000; Cortez et al., 2006). Essa diversidade pode ser responsável por falhas vacinais devido à inadequada proteção fetal contra as estirpes brasileiras do BVDV. Também em outros países é relatada a grande variabilidade antigênica de estirpes de campo do BVDV, que tem dificultado a obtenção de um espectro satisfatório de proteção por meio da vacinação (Hamers et al., 2001).

A ocorrência de sinais clínicos compatíveis com a infecção pelo BVDV nos animais avaliados no presente estudo a identificação de infecção aguda por esse vírus tanto em animais jovens quanto adultos a identificação de bezerros PI e o histórico de vacinação regular do rebanho sugerem que a infecção tenha sido causada por uma estirpe do BVDV para a qual as vacinas utilizadas não conferiram proteção cruzada plena. Somente estudos complementares, de caráter antigênico e molecular, a serem realizados nas duas estirpes do BVDV isoladas poderão elucidar a causa de falha vacinal identificada nesse rebanho.

O presente trabalho demonstrou que a RT-PCR constitui-se numa estratégia adequada para o diagnóstico etiológico da infecção pelo BVDV, mesmo quando utilizada em pools de soros sangüíneos. $\mathrm{O}$ emprego dessa técnica possibilitou aliar a redução no custo com a precocidade na conclusão do diagnóstico. Com isso, medidas de controle e profilaxia, como a eliminação de animais PI e mesmo a vacinação do rebanho, puderam ser conduzidas mais precocemente.

\section{REFERÊNCIAS BIBLIOGRÁFICAS}

BAKER, J.C. The clinical manifestations of bovine viral diarrhoea infection. Vet. Clin. N. Am.: Food Anim. Pract., v.11, p.425-445, 1995.

BOLIN, S.R. Control of bovine viral diarrhoea virus. Res. Sci. Tech. Int. Off. Epiz., v.9, p.163171, 1990.

BOOM, R.; SOL, C.J.A.; SALIMANS, M.M.M. et al. Rapid and simple method for purification of nucleic acids. J. Clin. Microbiol., v.28, p.495503, 1990.

BROCK, K.V. Diagnosis of bovine viral diarrhea virus infections. Vet. Clin. N. Am.: Food Anim. Prac., v.11, p.549-561, 1995.

CORTEZ, A.; HEINEMANN, M.B.; CASTRO, A.M. et al. Genetic characterization of Brazilian Bovine Viral Diarrhea Virus isolates by partial nucleotide sequencing of the 5'UTR region. Pesq. Vet. Bras., v.26, p.211-216, 2006.

DUBOVI, E.J. Impact of bovine diarrhea virus on reproductive performance in cattle. Vet. Clin. N. Am.: Food Anim. Pract., v.10, p.503-514, 1994.

FLORES, E.F.; WEIBLEN, R.; SCHERER, C.F.C. et al. Identificação do virus da diarréia viral bovina tipo 2 (BVDV-2) no sul do Brasil. Pesq. Vet. Bras., v.20, p.85-89, 2000.

FLORES, E.F.; WEIBLEN, R.; VOGEL, F.S.F. et al. A infecção pelo vírus da diarréia viral bovina (BVDV) no Brasil - histórico, situação atual e perspectiva. Pesq. Vet. Bras., v.25, p.125134, 2005.

HAMERS, C.; DEHAN, P.; COUVREUR, B. et al. Diversity among bovine pestiviruses: a review. Vet. J., v.161, p.112-122, 2001.

HOUE, H.; BAKER, J.C.; MAES, R.K. et al. Applications of antibody titers against bovine viral diarrhea virus (BVDV) as a measure to detect herds with cattle persistently infected with BVDV. J. Vet. Diagn. Invest., v.7, p.327-332, 1995.

HOUE, H. Epidemiological features and economical importance of bovine viral diarrhea 
virus (BVDV) infections. Vet. Microbiol., v.64, p.89-107, 1999.

McPHERSON, Q.P.; TAYLOR, G.R.; QUIRKE, P. PCR a pratical approach. Oxford: Information, $1994.247 \mathrm{p}$.

PEDRIZET, J.A.; REBHUN, W.C.; DUBOVI, E.J. Bovine viral diarrhoea: clinical syndromes in dairy herds. Cornell Vet., v.77, p.46-74, 1987.

PILZ, D.; ALFIERI, A.F.; ALFIERI, A.A. Comparação de diferentes protocolos para a detecção do vírus da diarréia viral bovina por RT-PCR em grupos de sangue total e de soro sangüíneo, artificialmente contaminados. Semina Cien. Agr., v.26, p.211-220, 2005.

ROSSMANITH, W.; VILCEK, S.; WENZL, H. et al. Improved antigen and nucleic acid detection in a bovine virus diarrhoea eradication program. Vet. Microbiol., v.81, p.207-218, 2001.

TAKIUCHI, E.; MÉDICI, K.C.; ALFIERI, A.F. et al. Bovine herpesvirus type 1 abortions detected by a semi nested-PCR in Brazilian cattle herds. Res. Vet. Sci., v.79, p.85-88, 2005.

VAN REGENMORTEL, M.H.V.; FAUQUET, C.M.; BISHOP, D.H.L. et al. Virus taxonomy: the classification and nomenclature of viruses. The seventh report of the International Committee on taxonomy of viruses, San Diego: Academic, 2000. $1167 \mathrm{p}$.

WEINSTOCK, D.; BHUDEVI, B.; ANTHONY, E.C. Single-tube single-reverse transcriptase PCR assay for detection of bovine viral diarrhea virus in pooled bovine serum. J. Clin. Microbiol., v.39, p.343-346, 2001. 